generally atypical. This change was marked in all three of the cases examined, alike in the bacilli obtained from the membrane and in those cultivated from the tissues.

TABLE IV.-Pyogenic or other Organisms.

\begin{tabular}{|c|c|c|c|}
\hline Bisease. & $\begin{array}{l}\text { Hours } \\
\text { after } \\
\text { death. }\end{array}$ & Organs examined. & Micro-organisms. \\
\hline 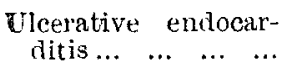 & $\{30\}$ & $\begin{array}{l}\text { Kidney, spleen, } \\
\text { anil heart. }\end{array}$ & $\begin{array}{l}\text { Staphylococcus } \\
\text { pyogenes albus. }\end{array}$ \\
\hline Empyema ... ... ... & 31 & Spleen. & Ditto. \\
\hline 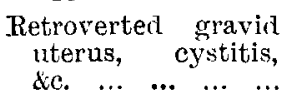 & $\{21$ & Spleen. & $\begin{array}{l}\text { Staphylococcus } \\
\text { citreus. }\end{array}$ \\
\hline $\begin{array}{c}\text { Acute infective osteo- } \\
\text { myelitis } \ldots \quad \ldots \quad \ldots\end{array}$ & $\xi 12\{$ & $\begin{array}{l}\text { Spleen, opcra- } \\
\text { tion wound, and } \\
\text { pleuritic abscess. }\end{array}$ & $\begin{array}{l}\text { Staphylococcus } \\
\text { pyogenes aureus. }\end{array}$ \\
\hline raumatic peritonitis & 12 & Peritoneum. & Staphylococcus. \\
\hline $\begin{array}{c}\text { Malignant disease of } \\
\text { the pancreas ... } \quad \ldots\end{array}$ & \} 20\{ & $\begin{array}{l}\text { (a) Spleen. } \\
\text { (b) Liver. }\end{array}$ & $\begin{array}{l}\text { (a) Bacilli (?) with } \\
\text { spores. } \\
\text { (b) Sterile. }\end{array}$ \\
\hline
\end{tabular}

One or other variety of staphylococcus (see Table 4) was most commonly developed. This is of interest in connexion with such diseases as ulcerative endocarditis and acute infective osteomyelitis in which the value of treatment by anti-streptococcic serum might be tested.

Clifton, Bristol.

\section{RECOVERY AFTER BULLET WOUND OF THE HEAD AND DESTRUCTION OF BRAIN TISSUE.}

BY ROBERT FENNER, L.R.C.P. EdIN., M.R.C.S. ENG., LATE SURGEON TO THE CROMER COTTAge HOSPITAL.

ON the evening of July 10th, 1897, a man, 42 years of age, who was watching some youths at revolver practice, was accidentally shot from a distance of two yards. Arriving on the spot about 30 minutes subsequently I found him insensible, breathing slowly and somewhat heavily but not stertorously. His pupils were dilated and did not react to light. He was bleeding from the mouth and blood was oozing from the nose. At the back of the head, about one and $a$ half inches to the right of the middle line and two inches above a line touching the upper margin of the external auditory meatus, there was a contused somewhat clean-cut wound from which blood was oozing and brain matter protruding. Having cut the hair and carefully cleansed and dressed the wound, rendering it as aseptic as possible, I caused him to be conveyed to the Cromer Cottage Hospital, a distance of two and a half miles. On admission he was practically in the same condition as above described but the pulse was slower and scarcely perceptible. Under an anæsthetic and with the assistance of Mr. H. C. Dent I exposed the wound by a large crucial incision through the scalp, turning up the four flaps well out of the way. Having thoroughly irrigated the wound and removed the protruding brain substance I found a circular and jagged hole in the skull admitting the little finger to the first joint. There was much splintering of the inner table and I could feel several large splinters of bone but no bullet even with a probe, although I could follow its track in a direction pointing to the right margin of the left orbit until the probe impinged upon hard bone. I now applied a large trephine and removed a circle of bone, taking in as much of the bullet wound as possible. Having removed several fragments of bone I made a careful examination of the track with my finger, passing it as far as I could reach into the cerebral substance, but I did not reach the bullet nor could I feel it with a long probe. The wound was copiously irrigated with a corrosive sublimate solution ( 1 in 4000), the mozzle of the irrigator being passed well into the brain, the flaps were sutured, and a small drainage-tube was left in position. The patient passed a quiet night but remained unconscious, blood continuing to ooze from the mose and mouth. On the following morning (July 11th) he bad partially regained consciousness but was irritable and was aroused with difficulty. The pulse-rate was 52 and the respirations were 16 . Hæmorrhage continued from the nose and mouth and the eyelids on both sides were much swollen. The next day the patient remained in an irritable condition, taking nourishment with difficulty. He was very restless and complained of pain in the head when questioned. The temperature was $101^{\circ} \mathrm{F}$.; the pupils were equal but not reacting to light. The wound was dressed. There had been much oozing of blood and as the flaps were bulging two stitches were removed. On July 14th the temperature was $100^{\circ}$. Both eyes were ecchymosed. The bleeding from the nostrils and mouth had ceased. The pupils were equal and reacting to light. The pulse was 54 . The patient was still irritable. Much brain substance was removed with this and subsequent dressings.

The patient remained in the same irritable condition until July 18th when he spoke rationally and could recall past events. He still complained of headache and was very drowsy and roused with difficuity. He had complete control over his bladder and bowels; his retinæ were examined and found to be normal, the reflexes were present and normal, and his senses of smell and taste were unimpaired. His temperature remained at $100^{\circ}$ or over until July 21st when it gradually reached the normal. Bleeding from the nose ceased and by July 28 th ecchymosis of the left upper eyelid alone remained. The patient gradually recovered strength and although somewhat irritable and childish he remembered past events perfectly and was quite rational. The hernia cerebri gradually became covered with healthy granulations and was completely healed by August 20th, at which date he left the hospital.

One year after the accident-viz., in July, 1898-the patient suffered from a slightly ataxic gait and an inability to see the left half of objects but otherwise he seemed none the worse for the injury.

This case illustrates the great amount of damage which can be borne by the cerebral substance provided the floor of the fourth ventricle and the sinuses are left intact. The bullet must have been flattened and irregular, having passed through a felt hat and the skull before ploughing up the brain substance. The course of the bullet was slightly upwards and to the left and the amount of bleeding from the nose and mouth and into the soft tissues surrounding the eyes point to the great damage sustained by the anterior fossa of the base of the skull. Although the chances of recovery appeared to be $n i l$ I trephined at once in order to anticipate tension and for the purpose of effective antisepsis and drainage.

I heard from the patient at Christmas, 1898-18 months after the accident-that with the exception of the partial loss of vision referred to he was completely restored to health and able to carry on his vocation. Dr. Johnson Taylor of Norwich kindly examined the patient's eyes and writes: "Your patient has left lateral hemianopsia due in all probability to an injury to the right optic tract or possibly to an injury to his right visual centre in the occipital lobe. The right half of each field and the central visual activity of each eye are normal. He reads $\frac{5}{5}$ with either eye and his accommodation is good. The ophthalmoscope shows a normal state of each fundus and the movements of the globe are normal; no other of his special senses seem in the least affected."

New Cavendish-street, $\mathrm{w}$.

\section{THE INFLUENCE OF RAINFALL ON BERI-BERI.}

By P. N. GERRARD, M.D. Dub.,

DISTRIOT SURGEON, UTU SELATgOR, FEDERATED MATAY STATES.

THe prevailing opinion amongst so many as I have had the pleasure of meeting of the members of the profession practising in the Malay Peninsula, where this disease causes such a very large number of deaths yearly, seems so much in favour of the supposition that cases of beri-beri occur more frequently during or after a wet month or that the severity of the cases is increased after wet weather that I have been led to collect the cases occurring in my district (Ulu Selangor, Malay States) for the past seven years. I have constructed a chart of the rainfall and beri-beri admissions for analysis 
and I hope to elicit remarks from other medical men who have had to deal with this most interesting and, I think I may say, badly understood disease. The total number of cases in the chart amounts to 2422 , extending over 84 months from February, 1891, to December, 1897, inclusive.

Calling the months in which a rise or fall of rainfall was accompanied by a similar rise or fall of beri-beri admissions, "Positive" evidence, and the contrary, "Negative," I obtained the following figures :-

\begin{tabular}{|c|c|c|c|}
\hline Months. & Positive. & & Negative. \\
\hline 6 Januaries $\quad . . . . . . . . . . .$. & 3 & 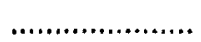 & 3 \\
\hline 7 Februaries ................ & 1 & (n.................. & 6 \\
\hline 7 Marches ................... & 3 & ...................... & 4 \\
\hline 7 Aprils ..................... & 3 & ...................... & 4 \\
\hline 7 Mays ......................... & 3 & ...................... & 4 \\
\hline 7 Junes ..................... & 4 & (..................... & 3 \\
\hline 7 Julys .......................... & 5 & ........................ & 2 \\
\hline 7 Augusts ................... & 2 & ....................... & 5 \\
\hline 7 Septembers ................ & 4 & ....................... & 3 \\
\hline 7 Octobers ................. & 4 & (...................... & 3 \\
\hline 7 Novembers .............. & 0 & ...................... & 7 \\
\hline 7 Decembers ............... & 1 & ...................... & 6 \\
\hline Totals............. & 33 & 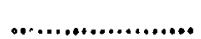 & 50 \\
\hline
\end{tabular}

This we may, I think, fairly consider as our first contradiction to the original proposition that " the rainfall influences beri-beri or the cause of beri-beri." Of the 83 months in this list we have only 33 showing positive evidence as against 50 showing negative; some of these, too, show such illbalanced proportion that they may be fairly excluded, as is shown in the following table*:-

In June, 1891, beri-beri shows a fall of 1 admission and rainfall 12 in. "July, 1892, beri-beri " , 2 cases and rainfall 10 inches. "June, 1895, beri-beri " " " 13 cases and rainfall $l$ inch. "May, 1896, beri-beri " " 5 cases and rainfall 8 inches.

"February, 1897, beri-beri shows a fall of 23 cases and rainfall 2 in.

"October, 1893, beri-beri shows a rise of 4 cases and rainfall 10 in.

* The word "fall" in this table means diminution both with regard to beri-beri and rain-e.g. in June, 1891, one case less of beri-beri was admitted than in the preceding month and 12 inches less rain fell than admitted than in the preceding month.

Deducting these cases from the positive evidence we get 27 months positive, six months neutral, and 50 negative, and, in fact, these six neutral may be treated as negative evidence. As an example of how I have arrived at the positive + or negative - evidence I quote in the following table the year 1892 as a sample, 1891 being one month short (where beri-beri rises and rainfall also rises the evidence is positive, the contrary negative) :-

\begin{tabular}{|c|c|c|c|}
\hline Month. & Evidence. & Beri-beri. & Ilainfall. \\
\hline January ... & Positive & Fell 32 to 16 cases & Fell 28 to 13 inches \\
\hline February .. & Negative & , 16,13 " & Rose 13,15, \\
\hline March ... ... & $"$ & Steady (13 cases) & , $15,20 \quad$, \\
\hline April $\ldots \quad .$. & ", & Rose 13 to 17 cases & +20 inches \\
\hline May $\quad \ldots \quad \ldots$ & $"$ & , 17,42 , & \pm 20 \\
\hline
\end{tabular}

The next point of contradiction I wish to draw attention to is that during the seven years under consideration the months in which the greatest amount of rain fell were not the months on which the greatest number of admissions took place, nor were the months next following the heaviest rainfall the correspondingly highest in admission except in one case-namely, in the seven Decembers during which taken together 99 inches fell, followed in six Januaries by a total of 232 cases, 232 being the fourth highest total of admissions and 99 the fourth highest of rainfall; this is a sop to the supporters of the "after rain beri-beri increase" theory, but it has not very much weight when it is considered that in the case of the other months (seren of each), altogether 70 months out of a possible 83 , the highest rainfall does not correspond with highest beri-beri; nor is highest rain followed the next month by beri-beri. The highest rain occurred in seven Octobers, accompanied by the seventh highest number of admissions of beri-beri and followed by the second highest number of admissions in seven Novembers. The second highest rain occurred in the seven Aprils accompanied by the fifth highest beri-beri list and followed immediately by the third highest beri-beri list in the seven Mays.
The third highest (Novembers) rain accompanies the second highest beri-beri and is followed by the highest beri-beri (Decembers). The fourth maximum rain (Decembers) accompanies the highest and is followed by the fourth maximum beri-beri. The fifth maximum rain accompanies the third highest beri-beri and is followed by the ninth beri-beri; the sixth rainfall accompanies the eleventh beri-beri and is followed by the seventh beri-beri; the seventh rainfall accompanies the ninth beri-beri and is followed by the tenth bcri-beri; the eighth rainfall accompanies the sixth beri-beri and is followed by the fifth beri-beri; the ninth rainfall accompanies the twelfth beri-beri and is followed by the eleventh beri-beri; the tenth rainfall accompanies the tenth beri-beri and is followed by the twelfth beri-beri; the eleventh rainfall accompanies the eighth beri-beri and is followed by the sixth beri-beri ; the twelfth rainfall accompanies the fourth beriberi and is followed by the eighth beri-beri. The maximum monthly rainfall for the seven years was in the following order: first Octobers, second Aprils, third Novembers, fourth Decembers, fifth Mays, sixth Septembers, seventh Junes, eighth Marches, ninth Augusts, tenth Julys, eleventh Februarys, and twelfth Januarys; whereas the maximum beri-beri admittances were in first Decembers, second Novembers, third Mays, fourth Januarys, fifth Aprils, sixth Marches, seventh Octobers, eighth Februarys, ninth Junes, tenth Julys, eleventh Septembers, and twelfth Augusts. The order of merit of the years with regard to rainfall and beriberi is shown in the following table:-

\begin{tabular}{|c|c|c|c|c|c|}
\hline-1 & \multicolumn{2}{|c|}{ The wettest year. } & \multicolumn{3}{|c|}{ Beri-heri admišsion order } \\
\hline 1 & 1891 & 250 in. (highest) & 1891 & 121 & 7 (lowest) \\
\hline 2 & 1892 & 178 inches & 1892 & 262 & 4 \\
\hline 3 & 1895 & 123, & 1895 & $4 \Sigma 8$ & 3 \\
\hline 4 & 1893 & 111, & 1893 & 242 & 5 \\
\hline 5 & 1894 & 110, & 1894 & 204 & 6 \\
\hline 6 & 1897 & 109 & 1897 & 445 & 2 \\
\hline 7 & 1896 & 104 in. (lowest) & 1896 & 700 & 1 (highest) \\
\hline
\end{tabular}

In 1892 the district began to show signs of waking up and mines began to be opened. Since this time the cases have steadily mounted until 1896, falling a little again in 1897. Through the courtesy of Messrs. Grey and Thomson of the district office I have had access to the district land books and bave found out the amount of land alienated by Government for mining purposes in each year as follows:-

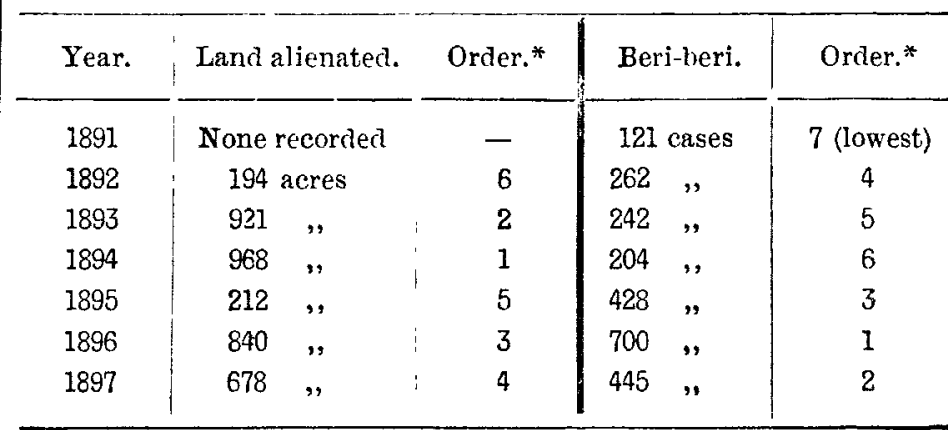

* The figures in these columns indicate the relative position of the years $1891-1897$ as regards the amount of land alienated and the number of cases of beri-beri.

The fact that the majority of miners are Chinese who very rarely open the ground at once, usually felling the jungle and then waiting for two years more or less before starting mining, coupled with the fact that everyone recognises that the district has become much busier in the last few years, will cause these figures to throw some light on the subject, although the amount of land alienated any given year does not bear any direct proportion to the number of cases that year. Allowing the usual two years for the land to lie unmined we find from the figures of the alienation of land that 1895,1896 , and 1897 ought to have produced the highest number of cases, and actually that is so, for during: the years 1893, 1894, and 18952201 acres were alienated. out of a total of 3813 , and during the years 1895, 1896, and 18971573 cases of beri-beri occurred out of a total of 2422 . considerably over half the amount of total land alienated and well over half the total number of cases in the sever years.

One more fact may be culled from the months in which 
the greatest amount of rain fell-viz., that they do not correspond with the highest beri-beri admissions in their individual position which may be seen on reference to the following table:- -

\begin{tabular}{|c|c|c|c|c|}
\hline \multirow{2}{*}{ Year. } & \multicolumn{2}{|c|}{ Rainfall. } & \multicolumn{2}{|c|}{ Beri-beri. } \\
\hline & Maximum. & Minimum. & Maximum. & Minimum. \\
\hline 1891 & October, 54 in. & March, 6 in. & $\left\{\begin{array}{c}\text { Decemlier, } 32 \\
\text { cases. }\end{array}\right.$ & $\begin{array}{c}\text { February and } \\
\text { October, } 5 \text { cases }\end{array}$ \\
\hline 1892 & June, 23 in. & August, 7 in. & May, 42 cases. & $\begin{array}{l}\text { February and } \\
\text { March, } 13 \text { cases }\end{array}$ \\
\hline 1893 & Octoher, $13 \mathrm{in.}$ & March, 3 in. & $\left\{\begin{array}{c}\text { December, } \\
35 \text { cases. }\end{array}\right\}$ & July, 7 cases \\
\hline 1894\{ & $\begin{array}{l}\text { April and De- } \\
\text { cember, } 14 \mathrm{in.}\end{array}$ & $\begin{array}{c}\text { February, } \\
\text { lin. }\end{array}$ & $\begin{array}{c}\text { April, } 34 \\
\text { cases }\end{array}$ & $\begin{array}{c}\text { September, } 5 \\
\text { cases }\end{array}$ \\
\hline 1895 & Octolver, 26 in. & January, I in. & $\left\{\begin{array}{c}\text { December, } 74 \\
\text { cases }\end{array}\right.$ & $\begin{array}{c}\text { February, } \\
\text { cases }\end{array}$ \\
\hline 1896 & October, 15 in. ? & $\begin{array}{l}\text { Jamuary aud } \\
\text { May, } 2 \text { in. }\end{array}$ & $\left.\begin{array}{c}\text { November, } \\
\text { cases }\end{array}\right\}$ & June, 36 cases \\
\hline 1897 & December, $20 \mathrm{in}$. & July, 5 in. & $\left\{\begin{array}{c}\text { January, } \\
\text { cases }\end{array}\right.$ & $\begin{array}{l}\text { July and De- } \\
\text { cember, } 20 \text { cases }\end{array}$ \\
\hline
\end{tabular}

It is also worthy of notice that the greatest number of admissions in any month for the several years occurred in 1891 in December, in 1892 in May, in 1893 in December, in 1894 in April, in 1895 in December, in 1896 in November, and in 1897 in January; and the highest rainfall each year occurred in 1891 in October, in 1892 in June. in 1893 in October, in 1894 in April and December. in 1895 in October, in 1896 in October, and in 1897 in December. From this may be seen that although four Octobers out of seven have shown the maximum rainfall, yet October does not occur in the beri-beri list of highest admittances and the month following - that is, November-only once.

These facts, coupled with the universal experience of the miners-namely, that when the mines are opened a certain large proportion of men will get beri-beri and a comparatively small number suffer from severe malarial feversseems in my opinion to point to the cause of the disease being in the soil or perhaps to its requiring the presence of malarial conditions or even parasites for its proper development.

[Dr. Gerrard next recapitulates the existing theories as to the etiology of beri-beri, but owing to the pressure on our space we have omitted this part of his paper. We have omitted his chart because the tabular statements make his arguments quite clear.]

It is beyond my province here to deal with such interesting points as the initial symptoms, the physical signs, progress, diagnosis, and treatment, all of which sub-divisions of this powerful and obscure disease require separate study, deep and honest, careful and concise, before we can hope to arrive at a true conclusion. I can only express a wish that the fact of its independence of meteorological vagaries may help to put us on our way to the commencement of that study which will begin on that date on which the cause is brought to light.

Since writing the above I have cultivated from the blood of an acute case of beri-beri a micrococcus somewhat similar to one described by Pekelhäring and Winkler, but not so irregular in size. I am forwarding slides to the School of Tropical Medicine. No bacilli were to be found on the plates or in tubes. I may also mention that the figures for 1898 endorse this argument against the influence of rainfall on this disease.

Ulu Selangor, Federal Malay States.

BeRKELEY Hospital.-The annual meeting of the managerial staff of this hospital was held on Fel. 1st under the presidency of Lord Fitzhardinge. The medical report stated that 75 cases had been admitted during the past year. The financial statement showed an adverse balance of $£ 61$ at the end of the year.

Dorset County Hospital.- - The annual meeting of governors, managers, and subscribers to the Dorset County Hospital, Dorchester, was held on Feb. 2nd under the presidency of Captain Acland. The report stated that during the past year 268 in-patients had been admitted and 868 out-patients attended. The financial statement showed that the income from all sources amounted to $£ 2356$ and the expenditure to $£ 2347$.

\section{A NOTE ON "CASES OF PHTHISIS WITH PECULIAR CARDIAC PHYSICAL SIGNS."}

By WILLIAM EWART, M.D. CanTaß., F.R.C.P. Lond., TENIOR PHYSICLAN TO ST. GWORGE'S HOSPITAL AND TO 'THE RELGRAVE HOSPITAL FOR CIIILINEN; JOIN'T LECI'URTR ON MFDICINE IN THE MEDTCAT SCHOOL OF ST. GEORGE'S HOSPI'AL.

UNDER the heading of "Cases of Phthisis with Peculiar Cardiac Physical Signs" two cases of great interest were recently reported in THE LANCET by Dr. Hale White ${ }^{1}$ and by Mr. W. Southwick Willmore ${ }^{2}$ which had until now escaped my notice. The physical signs noted were those 'of a great displacement of the heart to the right, yet at both necropsies the heart was found to be normal and not dis. placed. Both observers seem to accept the position that the displacement which they had diagnosed must have been apparent only, the cardiac sounds being conveyed by consolidated tissue, though they are at a loss to account for the impulse which in one case was felt and in the other was seen as well as felt in the right chest, and the conclusion arrived at is that "we must not assume that when the heart's impulse is seen and felt far on to the right side of the chest the organ is necessarily dragged or pushed over or altered in size." As any interpretation of the kind suggested might tend to shake that trust in our clinical methods of diagnosis which it is desirable that we should uphold, the time may not be thought to have passed for this reference to the cases and for an attempt to rid them of their mysterious character and to reconcile statements which were probably only in appearance contradictory. The clinical observations described are to my mind conclusive evidence of the existence during life of a considerable displacement of the heart to the right in both cases; but it is conceivable that this displacement could not be readily demonstrated by the ordinary post-mortem examination.

Cases of this sort occur from time to time among the large number of cases in which fibroid excavating disease of the right lung tends to displace the heart more or less. When at the same time the left lung and the heart are fixed by adhesions the right side of the thorax falls in. If the right chest should not fall in this must be due either to a considerable emphysematous distension of the right middle and lower lobes or, failing this, to the encroachment of the heart and of the left lung into the right chest. It is therefore clear that the cardiac displacements which are considerable and horizontal belong more especially to the group of cases in wbich, whilst the thorax remains symmetrical, the right lorver lobes are not only free from distension but are often themselves the seat of destructive lesions such as those reported in one of the two cases. Precisely similar cases have come under my own notice.

In January, 1891, closely adjoining beds were occupied by two patients under my care with destructive lesions in the right lung in whom the heart was much displaced, the cardiac dulness and impulse occupying in the right chest the position which normally belongs to them in the left. One of these patients, suffering from extensive bronchiectasis of the right lung, in wbom $\mathrm{Mr}$. Bennett had resected the right ninth rib at my request but had failed to obtain any discharge of pus, was exhibited at the Medical Society of London ${ }^{3}$ under the heading of "Dexiocardia" - a term properly restricted to the exceedingly rare cases in which the heart alone is congenitally transposed to the right, the other viscera not being transposed. Both patients died and were examined after death In the first case I happened to be prevented from witnessing the beginning of the necropsy and I was met on my way to the post-mortem room by a report that whilst the right lung was extensively excavated the relations of the heart were absolutely normal-a report which, not entertaining any doubt as to the reality of the displacement during life, i received with surprise and not without some reservation as to its retrospective significance. In our Post-mortem and Case Book (No. 64, 1891) may be seen facing each otber two equally trustwortby and accurate records, one describing the

1 Trm I ANCET, Nov. 19th, 1898, p. 1323.

of the Medical Society of London, vol. xiv., Feb. 16th, 1891 